$30: 1168$
＜原 著 $>$
メチルコラントレン誘導性ラット肝チトクローム P-450の
小葉内分布に関する検討

田村 信司

河田 純男 乾 由明

稲田 正已

野田 修造

斉藤 隆三

今井 康陽

三好 志雄

西川 正博

南 雄三*

岡本 光弘 山野 俊雄** 垂井清一郎*

要 旨：メチルコラントレン誘導性ラット肝チトクロームP-450（チトクロームP-450MC) に 対する抗体を作製し，蛍光抗体間接法を用いてメチルコラントレン投与をらけたラットにおけ るチトクローム P-450MCの経時的な肝小葉内誘導状態を観察した。またあわせて長期エタ ノール投与がチトクローム P-450MCに执よぼす影響についても同様に検討した。営光抗体間 接法におけるチトクローム P-450MCに対する特異蛍光は非誘導ラット肝において肝細胞細胞 質内に弱く認められ，その小葉内分布は小葉周辺域に比し中心域お上び中間帯でわずかに強い 傾向を示した.メチルコラントレン $20 \mathrm{mg} / \mathrm{kg}$ 体重の 1 回腹腔内投与後 $6 ， 12,24,48$ 時間に拉 ける特異営光の強さおよび小葉内分布の変化を検討した．特異営光の強さは時間が経るにつれ 増強し，その分布はすべて均一であった。 長期エタノール投与ラット肝と対照ラット肝の間に 特異営光の強さおよび分布に差を認めなかった。

柬引用語： チトクロームP-450 メチルコラントレン 肝小葉内分布 蛍光抗体間接法 長期エタノール投与

緒言

チトクロームP-450は薬物代謝反応1をはじめ胆汁 酸代謝 ${ }^{2}$, ステロイドホルモン代謝 ${ }^{3}$ 等に深く関与して おり，生体にとり重要な働きをしている。一方チトク ロームP-450は四塩化炭素4)や八口セン 5,6)等の代謝に おいて radical 中間体を産生させ肝障害を起こさせる ことやベンソ [a]ビレンや2-דセチルフミノフルオレ ン等の癌原物質の代謝において，これらの物質を活性 化し, 発癌性や変異原性を堌強する7)等, 生体にとり好 ましくない働きをすることる近年明らかになってきて いる、チトクロームP-450系により活性化されたこれ らの中間代謝物質は反応性に富むため，それらが産生 された近傍で障害を起こすと考えられる。よってそれ らの毒性や発癌性を論じるにあたりチトクロームP450の局在を明らかにすることは重要である。チトク ロームP-450は現在まで多くの分子種が同定されて打 り，各分子種によって特異基質が異なるほか，チトク

*大阪大学医学部第 2 内科

**大阪大学医学部生化学

<受付日60年 1 月 7 日 $>$
ロームP-450を誘導する種々の物質に対する誘導のさ れ方が異なっている8,9). 今回我々はメチルコラントレ ンで誘導したラット肝ミクロゾームチトクロームP. 4500 主成分であり，ベンソ〔a]ピレン等の癌原芳香 族炭化水素の代謝に特異性が高いとされるチトクロー ム $\mathrm{P}-450 \mathrm{MC}^{10)}$ の肝小葉内分布を検討した。 チトクロー ム P-450MCを精製，その抗体を作製し蛍光抗体間接 法を用いチトクロームP-450MC の肝小葉内分布およ びメチルコラントレン投与による肝小葉内分布の経時 的変化を明らかにした。

長期エタノール投与によりチトクロームP-450が誘 導されることが知られているが，近年エタノール特異 性のチトクロームP-450およびフェノバルビタール誘 尊性チトクロームP450が誘導されるとの報告がなさ れている11. 我々は長期エタノール投与によりチトク ロームP-450MCの誘導が認められるかについて子同 様に検討したので報告する。

$$
\text { 方 法 }
$$

1）チトクロームP-450MC の精製

Wistar 系雄ラット（体重200２50g）にメチルコラ 
ントレン $20 \mathrm{mg} / \mathrm{kg}$ 体重/日を 4 日間腹腔内投与した. 24時間絶食後屠殺し0.25M sucroseで還流した肝より ミクロゾーム分画を分離した．分離したミクロゾーム から Harada and Omuraの方法" $に$ 準じぁ. aminooctyl Sepharose 4B column, hydroxylapatite column, DEAE-Sepharose column, CM-Sepharose columnを用いチトクローム P-450MC を分離, 精製し た。チトクロームP-450は Omura and Satoの方法 ${ }^{12}$ で，蛋白はLowry の方法 ${ }^{13)}$ で測定した.

2）抗チトクロームP-450MC 家鬼抗体の作製

雄家鬼（体重約 $2 \mathrm{~kg}$ )に精製したチトクローム P-450 $\mathrm{MC}$ をワイント完全アジュバントとともに免疫し, その後 3 回ブースターをかけた，得られた抗血清から 硫酸フンモニウム塩析で免疫グロブリン分画を得た。

\section{3) 免疫組馧化学}

メチルコラントレン投与によるチトクローム P-450 $\mathrm{MC}$ の経時的な小菓内分布の变化, 抢上び長期ェタ ノール投与によるチトクローム P-450MCへの影響を 明らかにするため一群のラットにメチルコラントレン 投与拉よび長期エタノール投与を行ない肝組織内のチ トクローム P-450MC の分布の变化を虽光抗体間接法 を用い検討した。

メチルコラントレン投与ラット：Wistar 系雄ラッ ト（体重200g)にメチルコラントレン $20 \mathrm{mg} / \mathrm{kg}$ 体重を 1 回腹腔内投与し，投与 $6 ， 12 ， 24 ， 48$ 時間後に脱血 屠殺した．肝の一部を切除し凍結切片を作製した，残 りの肝は $0.25 \mathrm{M}$ sucrose で還流後，ミクロゾーム分画 を分離しチトクロームP-450量を湘定した。

長期エタノール投与ラット：Wistar 系雄ラット（体 重200g)に Lieber らの方法 ${ }^{(4)}$ にて長期エタノール投与 ラットを作製した。すなわち対照ラットには対照食を, 長期エタノール投与ラットには全カロリーの36\%をエ タノールで置换した飼料を 4 週間 pair-feeding した。 24時問絶食後脱血屠殺し旰の倲結切片を作製した。

作製した凍結切片は生理食塩りン酸緩衝液で洗浄後

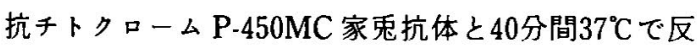
応させた。検体を洗浄後 fluorescein isothiocyanate 抗家鬼抗体羊血清と 40 分間 $37^{\circ} \mathrm{C}$ で反応させ，十分洗浄 後営光顕微鏡で観察した。

チトクロームP-450MCに対する虽光反応の特異性 は抗チトクローム $\mathrm{P}-450 \mathrm{MC}$ 家鬼抗体の代りに対照家 鬼血清を用いた染色および精製チトクロームP-450 $\mathrm{MC}$ と反応させその抗体結合部位をブロックさせた抗 チトクローム P-450MC 家鬼抗体を用いた染色を施行
し確認した。

$$
\text { 結 果 }
$$

精製チトクローム P-450MCの比含量は $16.3 \mathrm{nmol}$ P-450/mg 蛋白であった. Laemmli らの方法による SDS ゲル電気泳動にて単一パンドを示し分子量は約 56,000daltonsであった (Fig. 1).

精製チトクロームP-450MC と作製した抗体のマイ クロオクタロニー法を施行し，精製チトクロームP450MCに対応して沈降線を認めた（Fig. 2).

メチルコラントレン $20 \mathrm{mg} / \mathrm{kg}$ 体重の 1 回腹腔内投 与に上る経時的なチトクロームP-450量の变化を検討 した. ラット肝ミクロゾームチトクロームP-450比含 量は非誘導ラットで0.6nmol P-450/mg 蛋白であり, メチルコラントレン 1 回腹腔内投与 6 時間後 $0.7 \mathrm{nmol}$

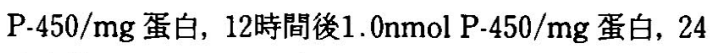
時間後 $1.2 \mathrm{nmol} \mathrm{P}-450 / \mathrm{mg}$ 蛋白, 48 時間後 $1.3 \mathrm{nmol} \mathrm{P}$. $450 / \mathrm{mg}$ 蛋白となりメチルコラントレン投与後時間が

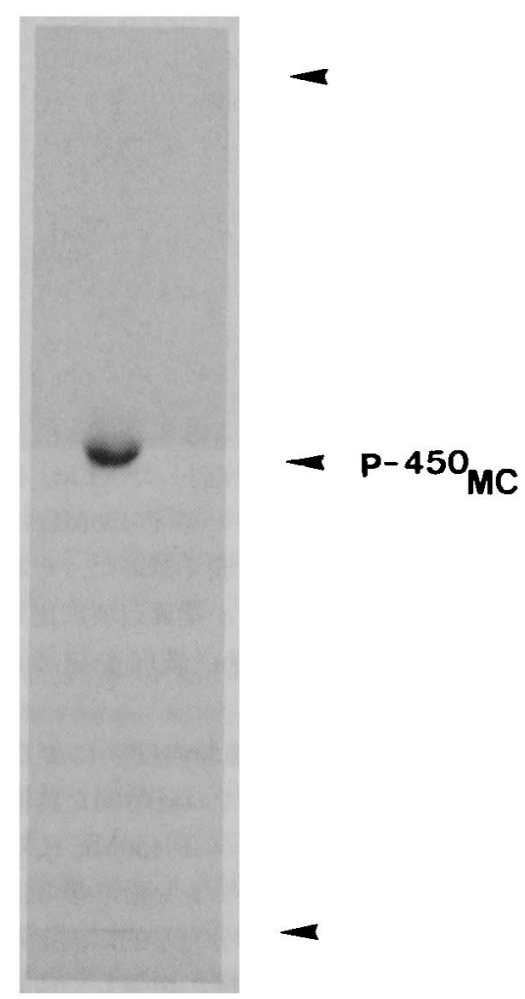

Fig. 1 Sodium dodecylsulfate-polyacrylamide gel electrophoresis of purified cytochrome P-450MC. Purified cytochrome P-450MC was analyzed by SDS-polyacrylamide gel electrophoresis on $10 \%$ gel containing $0.1 \% \mathrm{SDS}$. 


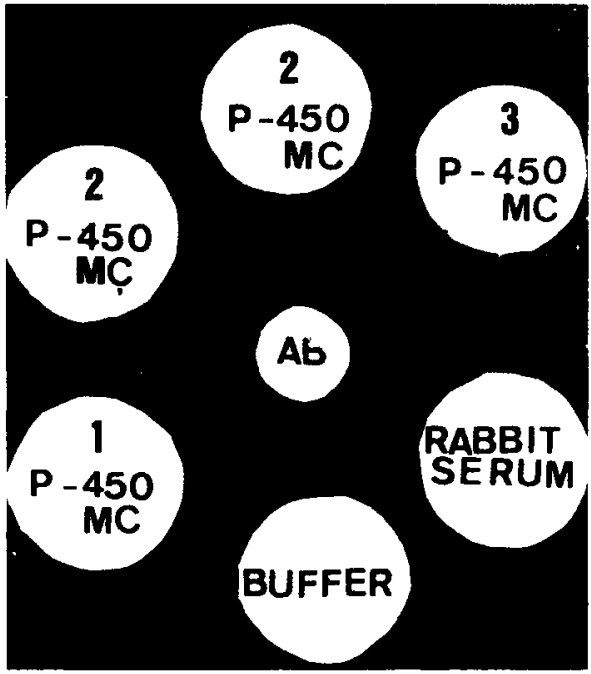

Fig. 2 Ouchterlony double diffusion test of rabbit antibodies against cytochrome P-450MC.

$\mathrm{Ab}$ : rabbit antibodies against cytochrome $\mathrm{P}-450$ MC. P-450MC 1: 0.5 nmoles of purified cytochrome P-450MC. P-450MC 2: 0.3 nmoles of purified cytochrome P-450MC. P-450MC 3: 0.2 nmoles of purified cytochrome P-450MC. SERUM : Non immunolized rabbit serum.

経るにつれてチトクロームP-450量の増加を認めた (Fig. 3). また誘導により還元 CO 差スペクトルでの ピークも450nmから $448 \mathrm{~nm}$ へと移行した。

\section{免疫組織化学的検討}

営光抗体間接法を用いラット肝におけるチトクロー ムP-450MCの局在について検討した（Fig. 4)。非誘 導ラット肝においてチトクローム P-450MCに対する 特異蛍光を肝細胞細胞質内に弱く認めた。 その小葉内 分布はほぼ均一であったが，小葉周辺域に比し中心域 おょび中間帯でわずかに強い傾向を認めた（Fig. 4-a).

メチルコラントレン 1 回腹腔内投与によるチトク ローム P.450MCの肝小葉内での経時的な誘導状態を 同様に検討した。チトクローム P-450MCに対する特 異虽光の強さはメチルコラントレン投与後 $6,12,24$, 48時間と時間が経るにつれ，分光学的に測定したチト クロームP-450量の増加と同様に増強してゆき，48時 間後が最も強かった。肝小葉内分布は投与後 $6 ， 12$, 24，48時間においてすべて小葉中心域，中間帯，周辺 域の間に差を認めない均一な分布となった（Fig. 4-b, c).
26巻 9 号 (1985)

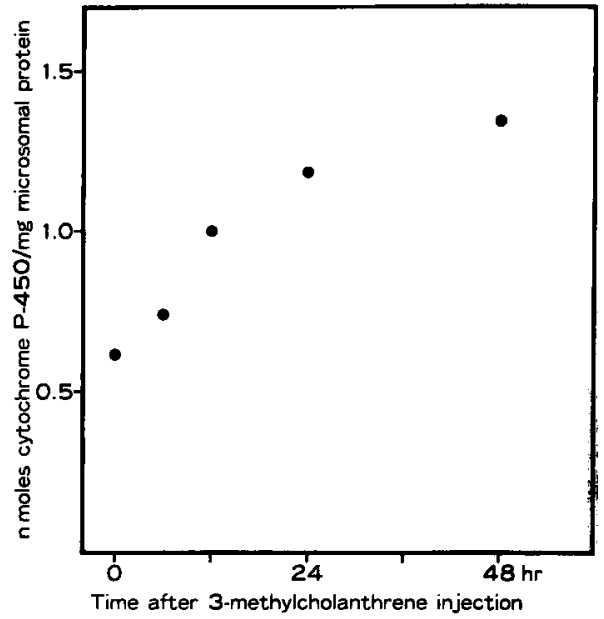

Fig. 3 Changes in the contents of cytochrome $P$. 450 in liver microsomes induced by 3 -methylcholanthrene administration.

長期エタノール投与ラットにおいても同様に虽光抗 体間接法を用い検討したが，対照ラットに比しチトク ローム P-450MC に対する特異学光反応は，その強さ および肝小葉内分布に差を認めなかった (Fig. 4-d).

\section{考察}

チトクロームP-450に関する研究が進むにつれある 種のハロゲン化炭化水素の代謝において free radical 等の中間代謝物質の産生 ${ }^{42)}$, ある種の癌原物質の活 性化?にチトクロームP-450が関与している事が明ら かになってきた。チトクロームP.450は多くの分子種 が同定されている。チトクロームP.450の基質特異珄 はかなり広いとされているか，それでも各分子種によ り相当明確に区別される基質特異性を有している． 今回我々が検討したチトクロームP-450MCは癌原性 芳香族炭化水素であるベンゾ[a]ピレンの代謝活性に 強い特異性を持っている(0) ルオレンの肝癌発生にも深く関与していることが報告 されている゙.

近年チトクロームP -4500 分子種により肝小葉内分 布が異なっていることが明らかにされた。フェノハル ビタールで誘導したラット肝ミクロソームチトクロー ムP-450の主成分であるチトクロームP.450PBは非 誘尊ラット肝において小葉中心域に主に局在してい る $^{15 \sim 17)}$. フェノハルビタール誘導により小葉中心域で の分布はやや広がるが，主な局在はやはり小葉中心域 から中間帯にある(6). 一方今回の我々の結果ではチト クローム P-450MC は非誘導ラット肝においてはぼ均 


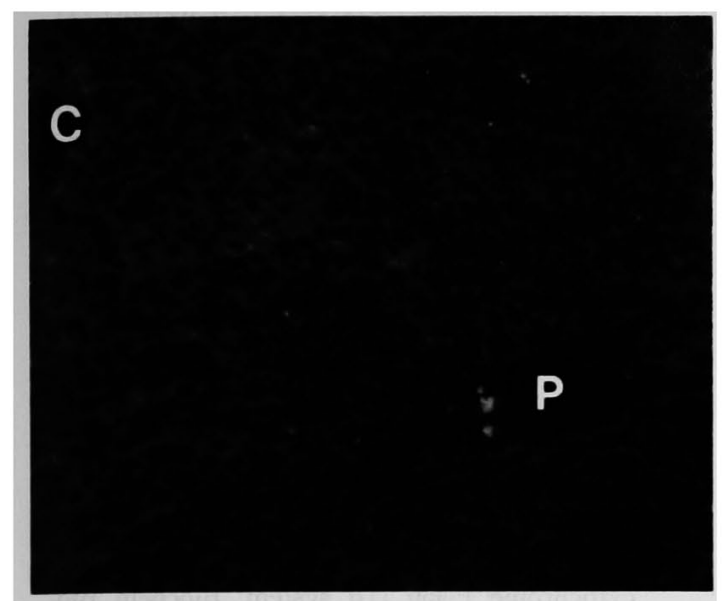

(a)

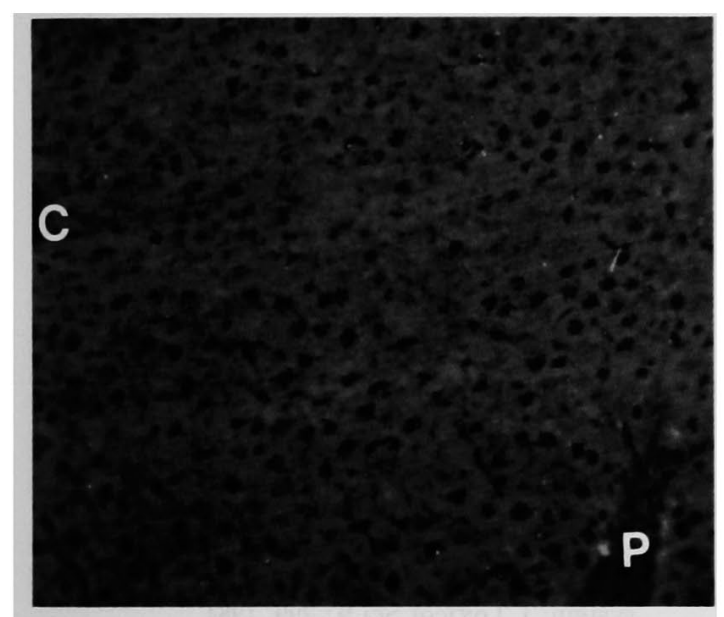

(c)

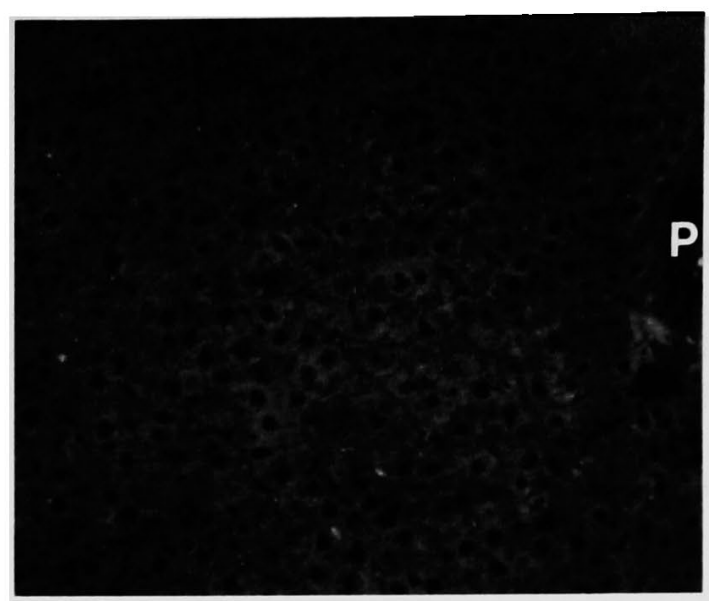

(b)

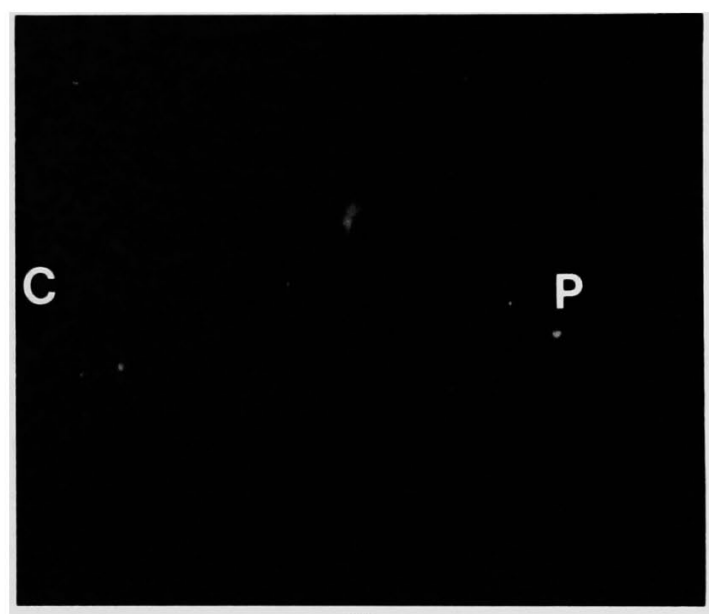

(d)

Fig. 4 Immunohistochemical localization of cytochrom p-450MC in the hepatic lobulus of control rat (a), the rat $6 \mathrm{~h}$ after injection of methylcholanthrene (b), the rat $48 \mathrm{~h}$ after injection of methylcholanthrene (c), and the rat fed with ethanol chronically (d).

Sections of liver tissue $(6 \mu \mathrm{m})$ from rats were exposed to rabbit antiserum against cytochrome $\mathrm{P} \cdot 450 \mathrm{MC}$ in the indirect fluorescent antibody staining protocol. A central vein (C) and portal triad (P) are indicated.

一に分布しており，小葉周辺域に比し中心域扰よび中 間帯でわずかに強い局在を認めたのみであった。また メチルコラントレン投与により均一な分布となり，千 トクロームP-450PBの分布および誘導のされ方と大 きく異なっていた。

チトクロームP.450MCの肝小葉内分布に関して Baron らは非誘導ラット肝に対して醭素抗体法およ び萤光抗体間接法を施行し, 我々とほぼ同様の結果を
報告している15). さらに彼らはメチルコラントレン25 $\mathrm{mg} / \mathrm{kg}$ 体重/日を 3 日間腹腔内投与し, 投与終了 24 時 間後のチトクロームP-450MCの小葉内での誘導状態 を蛍光抗体間接法における蛍光を測定することで非誘 導ラット肝と比較し, 中心域で150\%, 中間帯お゙び周 辺域で210〜225\%の増加があり，小莱中心域に比し中 間帯および周辺域でより大きな増加があると報告して いる(1). 今回我々はメチルコラントレン $20 \mathrm{mg} / \mathrm{kg}$ 体重 
を 1 回腹腔内投与しその後の経時的な肝小葉内での誘 導状態を検討した。 その結果投与後 $6 ， 12 ， 24 ， 48$ 時 間すべて均一な分布であり，時間が経るにしたがって 均一な分布のまま特異蛍光の増強を認めた。メチルコ ラントレンによるチトクローム P-450MC の誘導は 6 時間以内では小葉周辺域が中心域および中間帯に比し 大きな割合で誘導を受けると考えられるが，6時間以 後には 3 領域ともはぼ同じ割合で誘導を受けることが 明らかになった。

長期エタノール投与によりチトクローム P-450が誘 導されることが知られている。大西らは長期ェタノー ル投与ラットの肝ミクロゾームの SDS ゲル電気泳動 を施行し、チトクロームP-450PB とその他のェタノー ル特異性のチトクロームP-450が誘導され ${ }^{11}$ ，誘導さ れたチトクローム P-450PBの主な分布は小葉中心域 および中間帯になることを報告している17)。今回我々 は長期エタノール投与によりチトクロームP-450MC が誘導されるかを明らかにするため虽光抗体間接法で 検討した。 その結果長期エタノール投与ラット肝と対 照ラット肝との間にチトクロームP-450MCに対する 特異蛍光の強さおよび分布に差を認めず，チトクロー ム P-450MCは長期ェタノール投与に上り蛍光抗体間 接法で判定可能な程度の誘導は受けないことが明らか になった。

チトクロームP-450分子種間に㧊いて種々の誘導物 質に対する誘導のされ方やその誘導される部位の差が 認められるが，その原因については今後詳細に分析す る必要のある興味深い課題と考えられる。

\section{結 語}

チトクローム P-450MCに対する抗体を作製し，虽 光抗体間接法にてメチルコラントレン投与による肝小 葉内に护けるチトクローム P-450MCの経時的な誘導 状態および長期エタノール投与によるチトクローム P-450MCに対する影響を検討し以下の結果を得た。

(1) 非誘導ラット肝においてチトクロームP-450 $\mathrm{MC}$ に対する特異営光を肝細胞細胞質内に弱く認め, その分布は小葉周辺域に比し中心域および中間帯でわ ずかに強い傾向を認めた。

(2) メチルコラントレン $20 \mathrm{mg} / \mathrm{kg}$ 体重 1 回腹腔内 投与媵 $6 ， 12 ， 24 ， 48$ 時間にて検討したところ投与後 時間が経るにつれて特異営光は増強し，その小葉内分 布はすべてほぼ均一であった。

（3）長期エタノール投与ラット肝と対照ラット肝と の間に特異虽光の強さおよび分布に差を認めなかっ
た.

本研究の一部は文部省科学研究費補助金 (58570315)によ り行なった。

\section{文献}

1）市川佳幸，山野俊雄：シトクロムP-450水酸化醉 素系の再構成と今後の問題点. 生化学 50 : $77-86,1978$

2）奥田九一郎：コレステロール代謝に関与する肝葴 のチトクロームP-450．蛋白質・核酸・䤃素 26 ： 2143-2156, 1981

3) Wada A, Okamoto $M$, Nonaka $Y$, et al: Aldosterone biosynthesis by a reconstituted cytochrome P-450 $11 \beta$ system. Biochem Biophys Res Commun 119: 365-371, 1984

4) Albano E, Lott KAK, Slater TF, et al: Spintrapping studies on free-radical products by metabolic activation of carbon tetrachloride in rat liver microsomal fractions isolated hepatocytes and in vivo in the rat. Biochem J 204 : 593-603, 1982

5) Fujii K, Miki N, Kanashiro M, et al: A spin trap study on anaerobic dehalogenation of halothane by a reconstituted liver microsomal cytochrome P-450 enzyme system. J Biochem $91: 415-418,1982$

6) Tamura $S$, Nonaka $Y$, Minami $Y$, et al: Dehalogenation of halothane and 1-2-dibromoethane by rabbit liver microsomal P-450 system. J Toxicol Sci $9: 299,1984$

7) 田頭勇作, 川尻要, 米川博通：チトクロームP. 450の分子多様性と発癌物質の代謝活性化. 化学発 癌 $18: 815-823,1981$

8）今井嘉郎, 佐藤了：肝ミクロゾームのチトク 口ームP-450分子種の多様性と反応の多様性. 代 謝 $19: 1723-1735,1982$

9) Harada $N$, Omura $T$ : Selective induction of two different molecular species of cytochrome P-450 by phenobarbital and 3-methylcholanthrene. J Biochem 89: 237-248, 1981

10) Ryan DE, Thomas $P E$, Korzeniowski $D$, et al: Separation and characterization of highly purified forms of liver microsomal cytochrome $\mathbf{P}$. 450 from rats treated with polychlorinated biphenyls, phenobarbital, and 3-methylcholanthrene. J Biol Chem 254 : 1365-1374, 1979 
11) Ohnishi K, Lieber CS: Reconstitution of the microsomal ethanol oxidizing system. Qualitative and quantitative change of cytochrome P-450 after chronic ethanol consump. tion. J Biol Chem 252: 7124-7131, 1977

12) Omura T, Sato $R$ : The carbon monoxide-binding pigment of liver microsomes. J Biol Chem 239 : 2370-2378, 1964

13) Lowry OH, Rosebrough NJ, Farr AJ, et al: Protein measurement with the folin phenol reagent. J Biol Chem $193: 265-275,1951$

14) DeCarli LM, Lieber CS : Fatty liver in the rat after prolonged intake of ethanol with a nutritionally adequate new liquid diet. J Nutr $91: 331-336,1967$

15) Baron J, Redick JA, Guengerich FP: An immunohistochemical study on the localizations and distributions of phenobarbital-and 3-methylcholanthrene-inducible cytochrome P-450 within the livers of untreated rats. J Biol Chem 256 : 5931-5937, 1981

16) Kolyada AY : Immunohistochemical localization of cytochrome P-450 in rat liver. Bull Exp Biol Med 92 : 994-996, 1981

17）大西久石, 三島昭彦, 波多野等, 他：長期フル コール领用のラット肝フェノハルピタール誘導性 チトクロームP-450量，並びに小葉内分布に及ぼ す影隌。 日消誌 $80: 1281-1287,1983$

18) Baron J, Redick JA, Guengerich FP : Effect of 3-methylcholanthrene, $\beta$-naphthoflavone, and phenobarbital on the 3-methylcholanthrene-in. ducible isozyme of cytochrome P-450 within centrilobular, midzonal, and periportal hepatocytes. J Biol Chem 257 : 953-957, 1982

\title{
A study on the distribution of 3-methylcholanthrene-inducible cytochrome P-450 within the hepatic lobulus of rats
}

\author{
Shinji Tamura, Sumio Kawata, Yoshiaki InUI, Masami INada, Shuzo Noda, \\ Ryuzo SaITo, Yasuhiro IMaI, Shio MiYoshi, Masahiro NISHIKAWA, \\ Yuzo Minami*, Mitsuhiro OKamoto, Toshio Yamano** \\ and Seiichiro TARUI*
}

The effect of 3-mehylcholanthrene (MC) on the distribution of MC-inducible cytochrome P-450 (cytochrome $\mathrm{P}-450 \mathrm{MC}$ ) within the hepatic lobulus of rats was investigated by the indirect fluorescent antibody staining technique. Rabbit antiserum produced against cytochrome P-450MC was used in this experiment. The effect of chronic ethanol feeding on the distribution of cytochrome P-450MC in the hepatic lobulus was also studied. In the control rats, the specific fluorescence was barely observed, being slightly more intense in the centrilobular and the midzonal hepatocytes than in the periportal hepatocytes. The effect of $\mathrm{MC}$ on the distribution of cytochrome P-450MC was investigated at $6,12,24$ and 48 hours after peritoneal injection of $20 \mathrm{mg} \mathrm{MC} / \mathrm{kg}$ body weight. The intensity of the specific fluorescence increased with time and was almost equal among the three zones of the hepatic lobulus in all the stages investigated. No difference was observed between chronic ethanol feeding rats and control rats in the intensity and distribution of the specific fluorescence.

* The Second Department of Internal Medicine, Osaka University Medical School (Osaka)

** The Department of Biochemistry, Osaka University Medical School (Osaka) 